\title{
Editorial 2019: (2)1, Special Issue
}

\section{The Problem of Culture}

\section{Stephan Lafer, Special Issue Editor \& Bulent Tarman, Editor-in-Chief}

Culture is a phenomenon that is a potent force in the lives of human beings and many believe that respect for a person's culture is essential to respecting the person. The adverse, that to disrespect a person's culture is to disrespect the person, gives rise to an important concern that is to be considered in this edition. Because culture does influence character and is a force in shaping character, honest critique of culture and cultures is too often avoided for concern for the personal offense such might cause. Out of what is said to be the respect for individuals who are culture bound and sensitive about their culture, honest criticism of culture is pursued with overabundance of caution.

For this edition, it is expected from contributors that they take an honest look at culture and how culture can or does act to limit the development of the minds, the growth of individuals as individual thinkers. In this sense, culture exists in some instances, perhaps all, as an oppressive force, a particularly devastating force if it is thought important that individuals be allowed to discover the uniqueness of self as an intellectually competent human being.

The original purpose of this edition was to explore the limitations placed on cultural criticism and the profound problems for individuals and societies that that arise from unwillingness to explain culture fully, for what it is and the effect it has in limiting freedom and limiting thought. The original editor desired that articles explore the ramifications for culturally sponsored and culturally enforced limitation on the development of the human intellect and on the freedom of individuals to think as individuals. What harm is done when people are not allowed or discouraged from discovering the powers of their own minds, such discovery an essential phase in becoming fully human. As Freire tells us, the main problem plaguing our existence is dehumanization, actions by some that steal from others their basic humanity. He argues that humanization is a possibility, the motive for moving toward it a respect for others that is based in a proper respect for oneself, respect that comes with knowing that, as a human being, a person is capable of contributing to the betterment of the society in which he or she lives, a being of worth. That value to self and beyond of self to others resides in the uniqueness 
of individual mentality, in the ability of each to think originally. Valuing uniqueness is reason to value others enough to treat them humanely,

The purpose of schools should be to help their students discover their own intellectual powers, their ability to make sense of the world for themselves. Instead, they most often train them to accept and conform to cultural norms that may be virtuous and humane, but which are not. Schools, as conveyors of culture, prepare their students to be amenable to being controlled, to be accepting and uncritical of the culture in which the school is based. Right and wrong are made right and wrong without individuals being asked to consider much why right is right and wrong is wrong. Authority takes precedence over reason. The asking of necessary questions is discourage for what they might uncover. Religion overtly trains in this way. Schools are usually more subtle in their indoctrination, presenting as true the thought of other the culture recognizes to be its good thinkers, students make to know that they are not amongst these.

The original editor argued that a different kind of school is needed if humanization is to be the direction in which we human beings wish to head and humanization, as a goal, is absolutely necessary for the survival of human being and decent human societies. People have to know of their power to shape destiny and they have to know that it is by the force of human minds like their own that the better life will be found, the better way of life. Culture too often wants to hold back, to keep in place what is in place and those institutions that are bound to the culture, to its preservation, get in the way of change by convincing individuals that change is not possible, that they do not have the power to make change even when they know that change is necessary for living life decently and well.

Ivan Illich called for the "deschooling of society because, in his analysis, schools prevented people from becoming wise enough about what is real to participate effectively in the decision-making processes of democratic societies. To a great extent, people are taught to allow others to make decisions for them because, they are made to understand, they are not smart enough to do so for themselves. This is a cultural teaching, widespread, and it allows the many to be dominated by a relative few. 
The editor asked for articles that would address the claims he had made, to discuss in any variety of ways, the problems, and too, the virtues of culture and the possibility of schools that educated people in such a way that they would have the ability and know they had the ability to not only criticize culture but change culture so that life could be made more livable. The editor asked for response to the problem of cultural criticism, the sensitivities involved and the cost for individuals and societies in allowing culture to deprive people of their individuality and keep them from participating actively in creating cultures in which they truly want to live.

In this special issue, you will find nine articles. The first article written by Ricky Dale Mullins as titled 'Using Dewey To Problematize The Notion Of Disability In Public Education'. The main aim of this paper is examining ways in which students with disabilities have the capacity to be full, contributing citizens within a participatory, communicative, and pluralistic democracy. Mullins argued that in a Deweyian democracy, all students must have not just the right, but be allowed to grow in their capacity to develop into fully participating, contributing citizens.

Alexis Jones is the author of the second article entitled as 'Parallel Oppressions: Culturally-Enforced Limitations on the Individual's Humanity'. This article is a philosophical piece with snippets of empirical data shared to give an elaborate picture of what is currently done versus what is possible. Jones started with a review of theorists, old and new, who suggested that what is often implemented in American schools is very literally de-human-izing, especially as it relates to human nature, culture, and emotion. After developing the theoretical perspective, Jones presented several arguments that address what enormous potential American schools have, not only for educating our students in a way Freire would respect, but also for respecting our teachers' humanity at the same time.

The third article is written by Lori Turner Meier as entitled 'Questioning the Problematic Nature of School Culture in Elementary Teacher Education'. In this article, Meier aimed to serve as both commentary and plea to elementary teacher educators and gatekeepers. Meier asked the reader to consider that the culture of elementary teacher education, while characteristically an honorable and moral vocation, can indeed function as an oppressive and marginalizing force in the development, humanization, and growth of aspiring new teachers. 
Meier concluded with suggestions for ways the reader might consider a different, more humanized approach to individuality in elementary teacher education.

The forth article written by Stefani Boutelier as titled 'Limiting Learning Environments through Domestication'. The author analyzed the proliferation of domestication in American education systems inside and outside of the classroom. Boutelier used Don Miguel Ruiz's definition of domestication of children frames and engaged the reader to question their current practices and expectations of children and/or students.

In the fifth article 'Toward a Brilliant Diversity', Stefani Boutelier put forward a theoretical argument in support of culturally consonant character education. The author employed Charles Mills' The Racial Contract (1998) to not only account for the moralities of exclusion, but put forward a character education philosophy that accounts for cultural distinctiveness. The author tried to find an answer of the question, How can non-white, minority cultures foster their cultural distinctiveness in the character development process? Boutelier stressed that any character development process recognizes the collective memory, both cultural and historical, of non-white persons.

Abbie Strunc is the author of the sixth article entitled as 'The Politics of Culture: $A$ Discourse Analysis of the Texas Social Studies Curriculum'. In this article, Strunc aimed to examine Texas Social Studies Curriculum to determine how the educational culture is impacted by the social studies curriculum by using Van Dijk's socio-cognitive theory as a framework for discourse analysis. Strunc concluded that the language of the standards, the influence of outside sources, and the mandate from the state of Texas to teach these standards for the next ten years cultivate a social culture in public schools, which inserts a worldview, that does not consider other perspectives; and excluding ideologies from the curriculum is a dangerous practice.

The sevent article is written by Freyca Calderon-Berumen entitled as 'Resisting Assimilation to the Melting Pot: Validating the Cultural Curriculum of the Home'. In this article, Calderon-Berumen indicated that immigrants from diverse cultural and ethnic groups that try to keep some of their cultural traditions might encounter conflict when trying to adapt to their life in the new context. Calderon-Berumen contends for a cultural curriculum of the home 
endorsing family cultural values and traditions that is overlooked by schools and educators, disregarding its potential for enhancing children's learning process and academic achievement. The author concluded the study by proposing that schools keep trying to convince multicultural parents to do practices of parental involvement aligned with the dominant culture standards rather than recognizing and legitimizing the practices they already do and value as relevant and meaningful to their culture.

Matthew Etherington is the author of the eighth article entitled as "The Challenge with Educational Transformation: Rethinking the Mission to Educate in an Era of Change, Progress and Uncertainty" . In this article, Etherington argued that the challenge for this current generation of educators is to first recognize how they have been indoctrinated by ideas that ignore issues related to the diversity of the world's cultural commons.

In the last article, Chelsea T. Morris and Lindsey A. Chapman reviewed the 'Timeless Learning: How Imagination, Observation, and Zero-Based Thinking Change Schools' written by I. Socol, P. Moran, and C. Ratliff (2018).

We would like to thank everyone and express our special appreciation to the people who contributed to make this special issue ready for you. We especially would like to thank all authors and reviewers for their contribution to JCVE. We hope you will both enjoy and be challenged by the articles in this issue of JCVE. We also look forward to seeing your contribution to the development of JCVE in the future.

Looking forward to being with you in 2019 issues... 